\title{
Full-mouth rehabilitation in a Stevens-Johnson syndrome patient with severely worn dentition and abnormal root development
}

\author{
Yeon-Hee Park', Ri Ryu', Seung-Geun Ahn², Kyoung-A Kim³ ${ }^{3}$ and Jae-Min Seo ${ }^{4 *}$
}

${ }^{1}$ Resident, Department of Prosthodontics, School of Dentistry and Institute of Oral Bio-Science, Jeonbuk National University, Jeonju, Republic of Korea ${ }^{2}$ Professor, Department of Prosthodontics, School of Dentistry and Institute of Oral Bio-Science, Jeonbuk National University, Jeonju, Republic of Korea ${ }^{3}$ Assistant Professor, Department of Dentistry, School of Medicine, Eulji University, Daejeon, Republic of Korea

${ }^{4}$ Associate Professor, Department of Prosthodontics, School of Dentistry and Institute of Oral Bio-Science, Jeonbuk National University, Jeonju, Republic of Korea

Stevens-Johnson syndrome (SJS) is a cytotoxic immune disorder that causes serious damage to the skin and mucous membranes. SJS is a rare disorder that is triggered by particular medications or infections. De Man (1979), for the first time, described an abnormal root development due to SJS. While systemic complications were frequently reported, the abnormal root development in SJS has been rarely reported as an oral and maxillofacial complication of SJS. In this case report, a 26-year-old woman who had experienced SJS at the age of 9 year exhibited excessive tooth wear on whole dentition. While multiple teeth with incomplete root development showed slightly increased mobility, these teeth were not pathological and were erupted up to their normal functional position. Therefore, full-mouth rehabilitation procedures were completed to protect the worn dentition and improve the masticatory function and anterior esthetics.

Key Words: Dental enamel hypoplasia, Mouth rehabilitation, Stevens-Johnson syndrome, Tooth abnormalities, Tooth wear

(c) This is an open-access article distributed under the terms of the Creative Commons Attribution Non-Commercial License (http://creativecommons.org/licenses/by-nc/4.0) which permits unrestricted noncommercial use, distribution, and reproduction in any medium, provided the original work is properly cited.

\section{Introduction}

스티븐스-존슨 증후군(Stevens-Johnson syndrome, SJS)은 피부와 점막에 심각한 장애를 일으키는 세포독성 면역질환으 로 약물이나 감염에 의해 야기되는 질환으로 매년 100 만명 당 1 명꼴로 발병하는 드문 질환이다. 일반적으로 감기와 같은 증 상으로 시작하며, 뒤이어 통증을 유발하는 적색 혹은 보라색 의 발진을 일으키고 구강, 코, 눈, 성기의 점막에 수포를 형성하 며 퍼진다[1]. 1860년 최초로 Von Hebra [2]가 점막 이상이 없 고 전신 증상이 없는 가벼운 피부질환으로 삼출다형홍반을 보 고한 이래로 많은 논문에서 $\mathrm{SJS}$ 에 대한 전신적인 결과를 보고
하였다. 1922년 Stevens과 Johnson [3]은 두 가지 사례를 참고 하여 이 증후군을 다시 보고하였고, 이 두 가지 사례에서는 삼 출다형홍반, 구내염, 결막염 및 전신 증상을 보였다. 또한 SJS와 관련된 합병증으로는, 1866년 Von Hebra [2]의 보고에서 폐렴 을 동반하였고, 그 외에 심근손상, 간세포의 퇴행변화, 횡단척수 염, 신염, 급성 요세관 괴사 등이 보고되었다[4-6]. Wanscher와 Thormann [7]은 영구적인 무조증(permanent anonychia)이 SJS 발병 후에 나타났다고 보고하였다.

$\mathrm{SJS}$ 와 관련된 전신적 합병증에 대한 많은 보고가 있는 반면, 구강악안면 부위와 관련된 보고는 거의 없었다. 비정상적인 치 근발육은 1979년 De Man [8]에 의해 처음 보고되었으며, 이는

Received July 23, 2020; Revised August 24, 2020; Accepted August 26, 2020

${ }^{*}$ Corresponding author: Jae-Min Seo, Department of prosthodontics, School of Dentistry and Institute of Oral Bio-Science, Jeonbuk National University, 20 Geonji-ro, Deokjin-gu, Jeonju 54907, Republic of Korea.

Tel: +82-63-250-2696, Fax: +82-63-250-2218, E-mail: jmseo@jbnu.ac.kr

Copyright $\odot$ 2020, Oral Biology Research Institute 
SJS로 인한 합병증으로 빈번하게 알려지지 않았다. 본 증례에 서는 SJS 병력으로 인하여 구강악안면 관련 합병증을 가진 환자 로 전반적인 치아에서 심한 마모와 부분적인 치관파절을 지녔 으며, 불완전한 치근발육으로 치아는 약간의 동요도가 증가되 어 있으나 병적이지 않았고, 모두 교합면 높이까지 맹출하여 있 었다. 따라서 악간관계, 수직고경, 교합평면, 심미성, 측두하악 관절 상태 등을 종합적으로 평가, 진단하여, 마모된 치아를 보호 하고 지속적인 마모진행을 예방하기 위하여 전치부는 심미적인 전부도재관으로, 구치부는 기계적 물성이 우수한 지르코니아 전장관으로 보철 수복을 시행하여 기능적, 심미적으로 개선된 결과를 보였기에 이를 보고하고자 한다.

\section{Case}

본 증례의 환자는 26 세 여성으로 전 치열의 심한 마모와 부분 적인 치관 파절로 인하여 진단 및 치료를 위해 타 병원에서 의뢰 되었으며 잘 씹히지 않는다는 불편감을 호소하였다. 전신병력 청취 결과 이전에 SJS를 진단받아 좌측에 의안으로 가진 것 이외 에 특이할 만한 치과적 병력이나 측두하악관절 장애, 비기능적 악습관은 없었다.

구강 내 검사 결과 하악 우측 제1대구치(\#46) 상실과 하악 좌 측 제2대구치(\#37) 함입이 있었고, 다수 치아에 이전에 치료받 은 아말감 및 레진 수복물이 있었다. 상악 전치의 설면과 구치부 교합면의 심한 마모 및 부분파절을 보였으며, 나머지 치아에서 도 중등도의 마모와 부분파절, 짧아진 치관을 보였다. 치근 발육
이 중단된 일부 치아에서 동요도가 증가된 상태였으나 병적이 지 않았고, 모든 치아는 교합면의 기능적 위치까지 도달하였다. 하악 우측 제 1 대구치(\#46) 상실부위의 협설측 치조골이 위축되 어 있었으며(Fig. 1), 방사선사진 검사 결과 상하악 제1대구치, 상하악 4전치를 제외하고는 비정상적인 치근 발육 및 전반적인 치아에서 작은 치수강을 보였다(Fig. 2).

환자의 교합관계를 평가하기 위해 예비인상 채득하여 진단 모형 제작하였다. 먼저 구치부 치아가 접촉되지 않게 양측 전방 부 치아에 contton roll을 수 분 동안 물려 근육 재설정(muscle deprogramming)을 유도한 후, 양수조작법을 이용하여 자가중 합형 아크릴릭레진(Tokuso Curefast; Tokuyama Dental Co., Tokyo, Japan)으로 anterior jig를 제작하고 중심위를 채득하였 다. 안궁 이전하여 반조절성 교합기(Hanau Modular Articulator System; Whip Mix Co., Louisville, KY, USA)에 부착하여

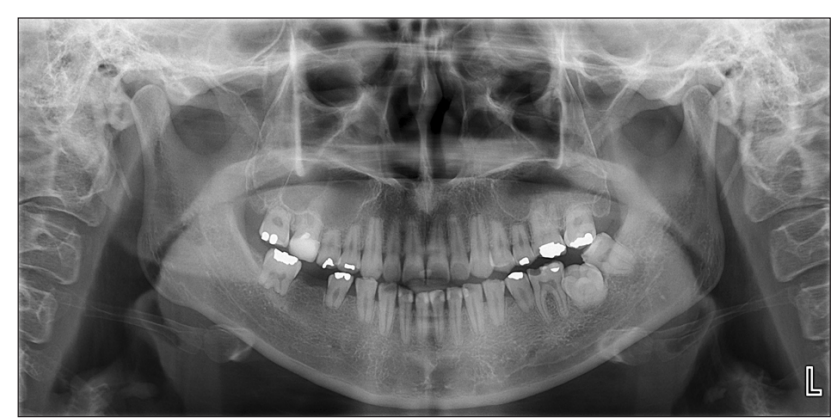

Fig. 2. Pre-treatment panoramic radiograph.

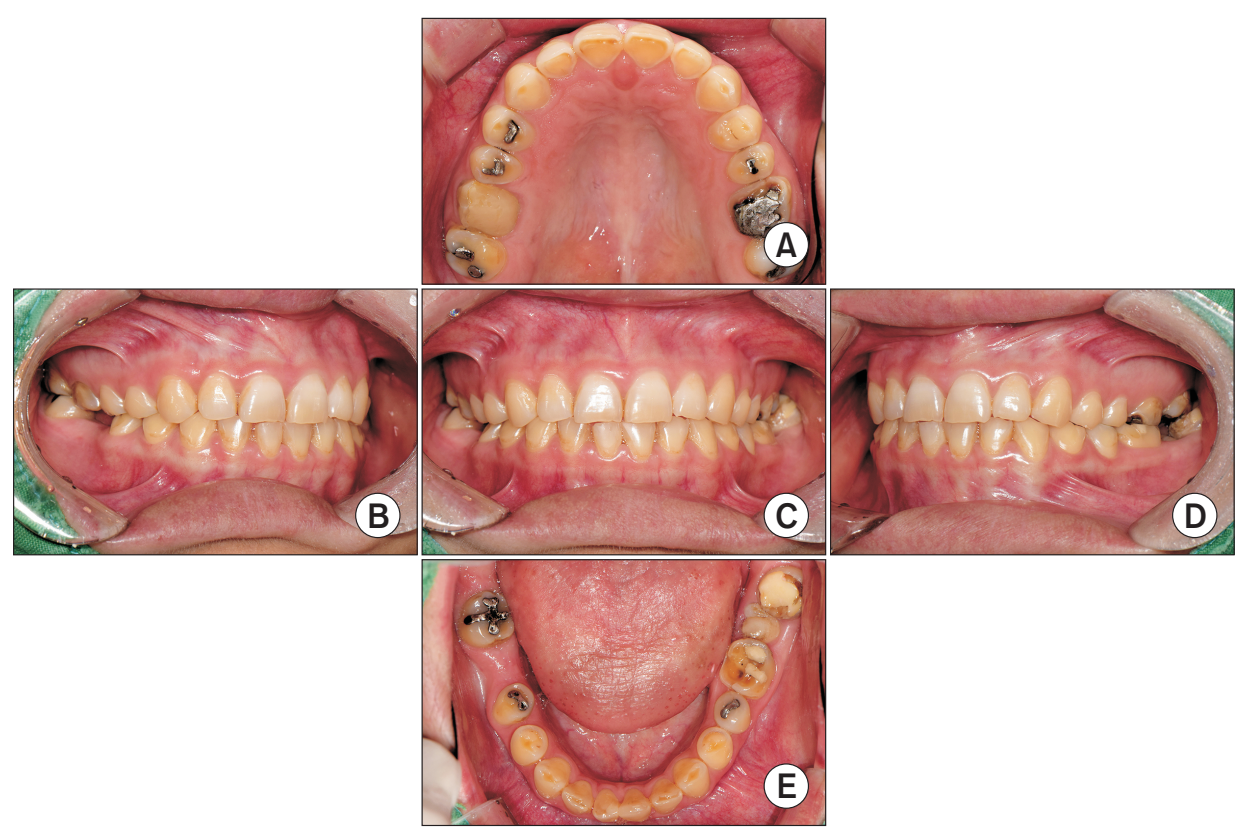

Fig. 1. Pre-treatment state. (A) Maxillary occlusal view, (B) right lateral view, (C) frontal view, (D) left lateral view, (E) mandibular occlusal view. 
진단모형 분석을 시행하였다. 전반적인 치아 마모와 짧은 치관 길이를 확인하였다. 법랑질이 닳아 cupping 현상을 보이고, 수 평피개와 수직피개가 부족하였다(Fig. 3).

수직고경 평가를 위한 검사 및 분석을 시행하였다. 방사선 사 진에서 측두하악관절의 과두 형태 및 위치는 정상적인 모습이 었고, 병적 소견은 관찰되지 않았다. 한국인 성인의 평균 중절치 치관길이를 상악은 $10.0 \mathrm{~mm}$, 하악은 $8.0 \mathrm{~mm}$ 로 설정하였을 때 [9], 환자의 중절치의 해부학적 길이는 상악은 $8.0 \mathrm{~mm}$, 하악은 $6.5 \mathrm{~mm}$ 로 작은 값을 보였다. 또한 상, 하악 중절치 치은연 간 거 리는 $14.0 \mathrm{~mm}$, 견치부위의 상, 하악 순측 전정 간 거리는 33.0 $\mathrm{mm}$ 로 평균인 $35.0 \mathrm{~mm}$ 보다 작은 값을 보였다(Fig. $4 \mathrm{~A}$ ) [10]. Willis [11] 법을 이용한 안면 계측 결과 동공에서 구각까지의 거리는 $70.0 \mathrm{~mm}$, 코끝에서 턱끝까지의 거리는 $62.0 \mathrm{~mm}$ 로 하 안모의 길이가 감소된 소견을 보였다(Fig. $4 \mathrm{~B}$ ). 교합면간간극 (freeway space)은 약 $3 \mathrm{~mm}$, 최소발음공간(closest speaking space)은 $1 \mathrm{~mm}$ 로 나타났다[12]. 이상의 임상적, 방사선학적 평 가 기준과 환자의 비정상적인 마모 등을 평가하였을 때, 급격하 고 과도한 마모에 비해 상대적으로 치아의 보상적 맹출이 적어 소량의 교합고경의 소실이 발생했다고 판단하였다.

따라서 마모된 치아를 보호, 회복하고 전치부의 적절한 수평 피개와 수직피개를 부여하고 심미성을 개선하기 위해 수직고경 거상을 동반한 전악 보철수복을 하기로 결정하였다. 하악 우측
제1대구치(\#46) 상실부위는 임플란트 지지 고정성 보철수복하 고 합입된 하악 좌측 제2대구치(\#37) 는 교정치료를 이용하여 구치부 직립시키며 나머지 자연치아는 고정성 보철 수복하기로 결정하였다. 중절치를 기준으로 $2 \mathrm{~mm}$ 를 거상한 후, 전치부 및 구치부 교합관계를 심미적, 기능적으로 수정하여 진단납형을 제작하였다. 상악 전치부 길이는 한국 여성 평균인 9 10 mm, 하악 전치부 길이는 8 9 mm로 설정하고 수평피개 $2 \mathrm{~mm}$, 수직 피개 $2 \mathrm{~mm}$ 로 수정하여 상악 전치가 하악 절치를 $1 / 3$ 정도 피개 하도록 하였다(Fig. 5). 하악 좌측 제2대구치(\#37) 구치부 직립 을 위한 교정치료 도중 교합 및 턱관절 변화 가능성으로 교정치 료 이후 보철수복을 진행하기로 하였고, 교정치료 중간에 하악 우측 제1대구치(\#46) 임플란트 식립하기로 계획하였다. 교정치 료 중간에 하악 우측 제1대구치(\#46) 임플란트 식립을 위한 진 단모형 및 진단용 스텐트를 제작하여 이를 이용하여 콘빔전산 화단층촬영(Cone Beam computed tomography) 시행 후(Fig. $6 \mathrm{~A})$ 하악 우측 제1대구치(\#46) 부위에 임플란트(4.5X10mm; Superline, Dentium, Seoul, Korea) 식립하였다(Fig. 6B). 교정 치료 도중 교정치료 기간이 매우 길어질 것으로 예상되었고, 전 반적인 치아 마모 및 파절이 더욱 심하게 진행되어 좌측 상하악 대구치를 제외한 전악 수복을 먼저 진행하기로 치료계획을 변 경하였다. 또한, 하악 좌측 제2대구치(\#37) 의 설측 전위가 심하 여 이를 교정적으로 직립시키기에는 하악 좌측 제3대구치(\#38)
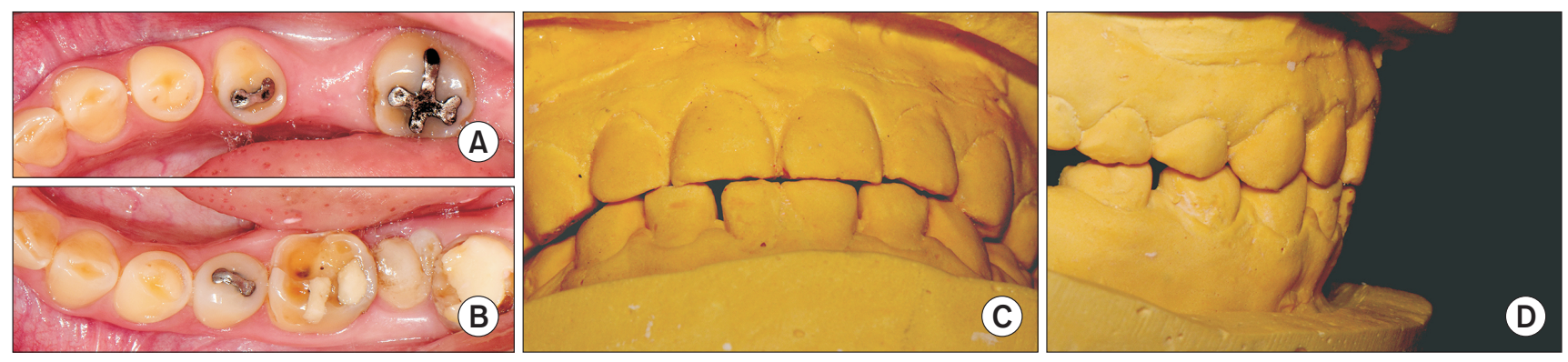

Fig. 3. Intraoral examination and diagnostic cast analysis. (A, B) Dental cupping. (C, D) Shallow overjet, overbite.
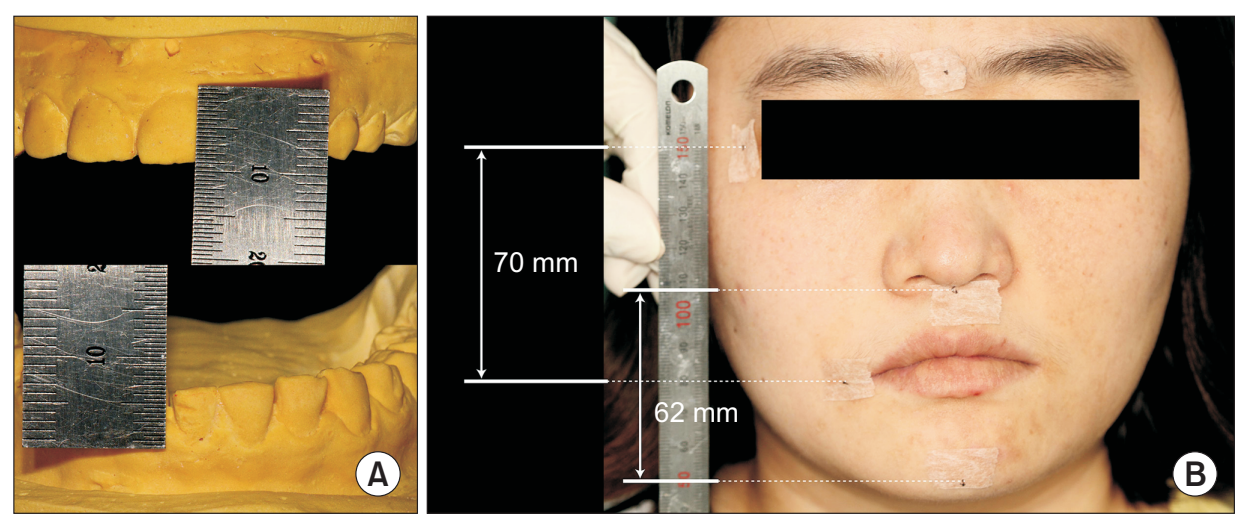

Fig. 4. Evaluation of vertical dimension. (A) Measurement of crown length, (B) willis method. 

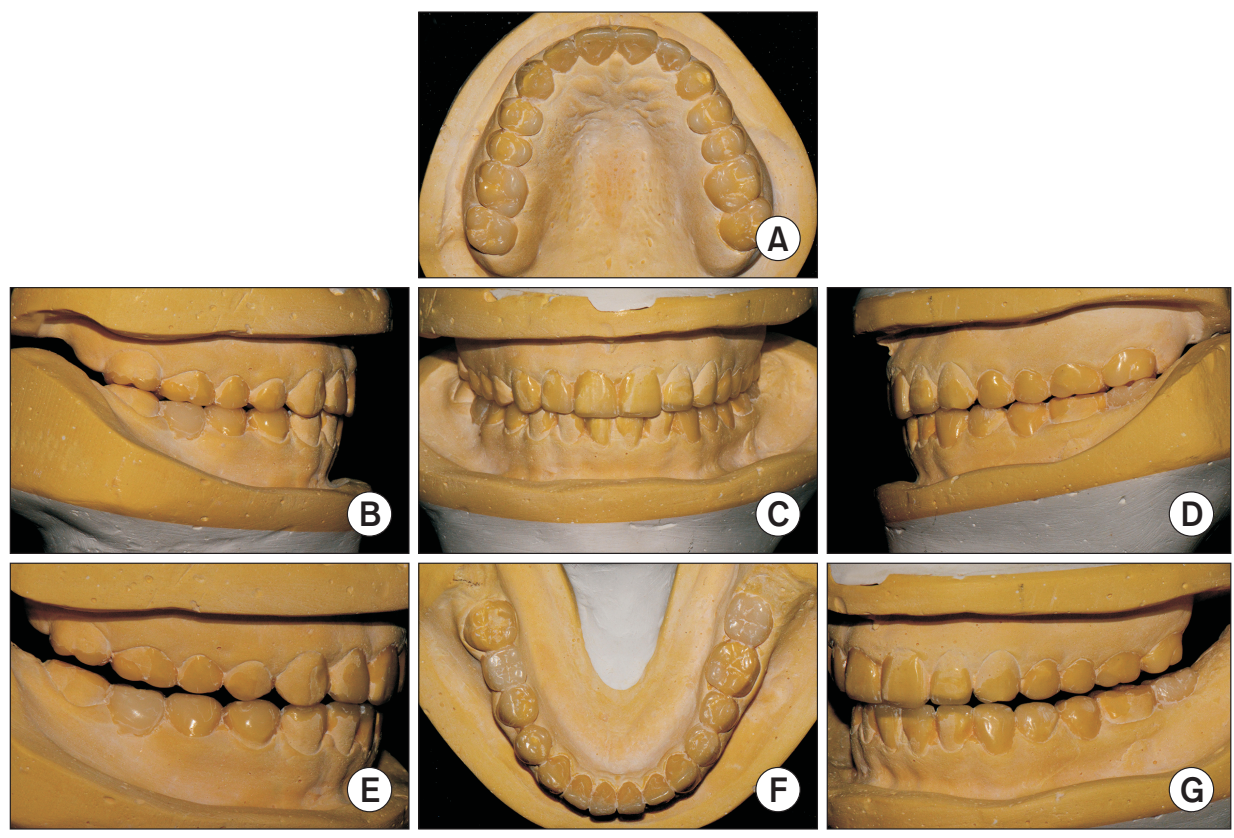

Fig. 5. Diagnostic wax-up model. (A) Maxillary occlusal view, (B) right lateral view, (C) frontal view, (D) left lateral view, (E) lateral movement-right side, (F) mandibular occlusal view, (G) lateral movement-left side.
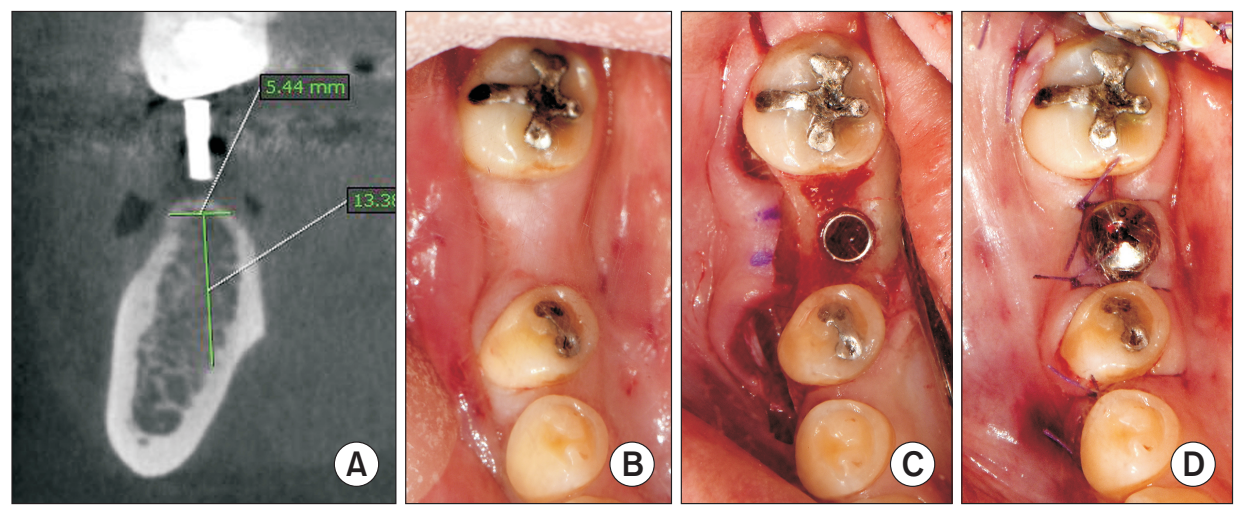

Fig. 6. Preoperative diagnosis for dental implant. (A) Cone beam computed tomography images for implant placement in mandibular edentulous area, (B-D) \#46 implantation.

의 이동량이 많아 직립이 어려울 것으로 판단되어 해당치아 발 거 후 하악 좌측 제3대구치(\#38)를 전방부로 견인하는 것으로 교정치료계획도 변경하였다(Fig. 7). 상하악 좌측 대구치를 제외 한 치아 삭제를 시행하였으며, 진단납형을 스캔 후 polymethyl methacrylate (PMMA)로 제작한 임시보철물을 구강 내에서 재 이장하여 환자에게 장착하였다. 교합조정 통해 전치부를 포함 한 전체 치아에 균등한 교합점을 형성하였고, 측방운동 시 견치, 그리고 전방운동 시 상악 한 쌍의 중절치에 의해 유도됨을 재확 인하였다(Fig. 8). 하악 우측 제1대구치(\#46) 임플란트는 치유지 대주를 연결한 상태에서 하악 제2소구치(\#45)-하악 제2대구치 (\#47) 3-unit 임시보철물의 가공치 하방을 지지하도록 하다가, 추후 맞춤형 지대주와 단일 임시보철물로 전환하였다. 전악의 임시보철물을 5 개월 동안 사용하여 환자의 적응도를 평가하였 고, 이 기간 동안 어떠한 합병증도 관찰되지 않았고, 환자는 기
능적, 심미적으로 만족하였다.

하악 좌측 구치부의 교정치료 기간이 길어질 것을 고려하 여, 상하악 좌측 구치부를 제외한 나머지 모든 지대치의 최종 보철물을 제작하기로 결정하였다. 부가중합형 실리콘 인상재 (Aquasil Ultra XLV, Monophase; Dentsply Caulk, Milford, $\mathrm{CT}, \mathrm{USA}$ )를 이용하여 최종인상 채득하고, 작업 모형을 제작하 였다(Fig. 9). 임시보철물 수복된 상태에서 안궁이전 시행하고 모형으로 제작하였으며, 개인 맞춤형 절치유도판 제작을 통해 임시보철물 상태의 전치부 형태와 교합관계를 최종보철물 제 작에 반영하였다(Fig. 10). 전치부 임시보철물을 전방 정지점 으로 하여 부가 중합형 실리콘(O-bite; DMG, Hamburg, Germany)로 중심위 악간관계를 채득하여 교합기상에서 작업모형 을 교차부착(cross-mounting)하였다. 환자의 젊은 나이를 고 려하여 전치부는 자연치와 유사한 색조와 투명도를 갖도록 리 


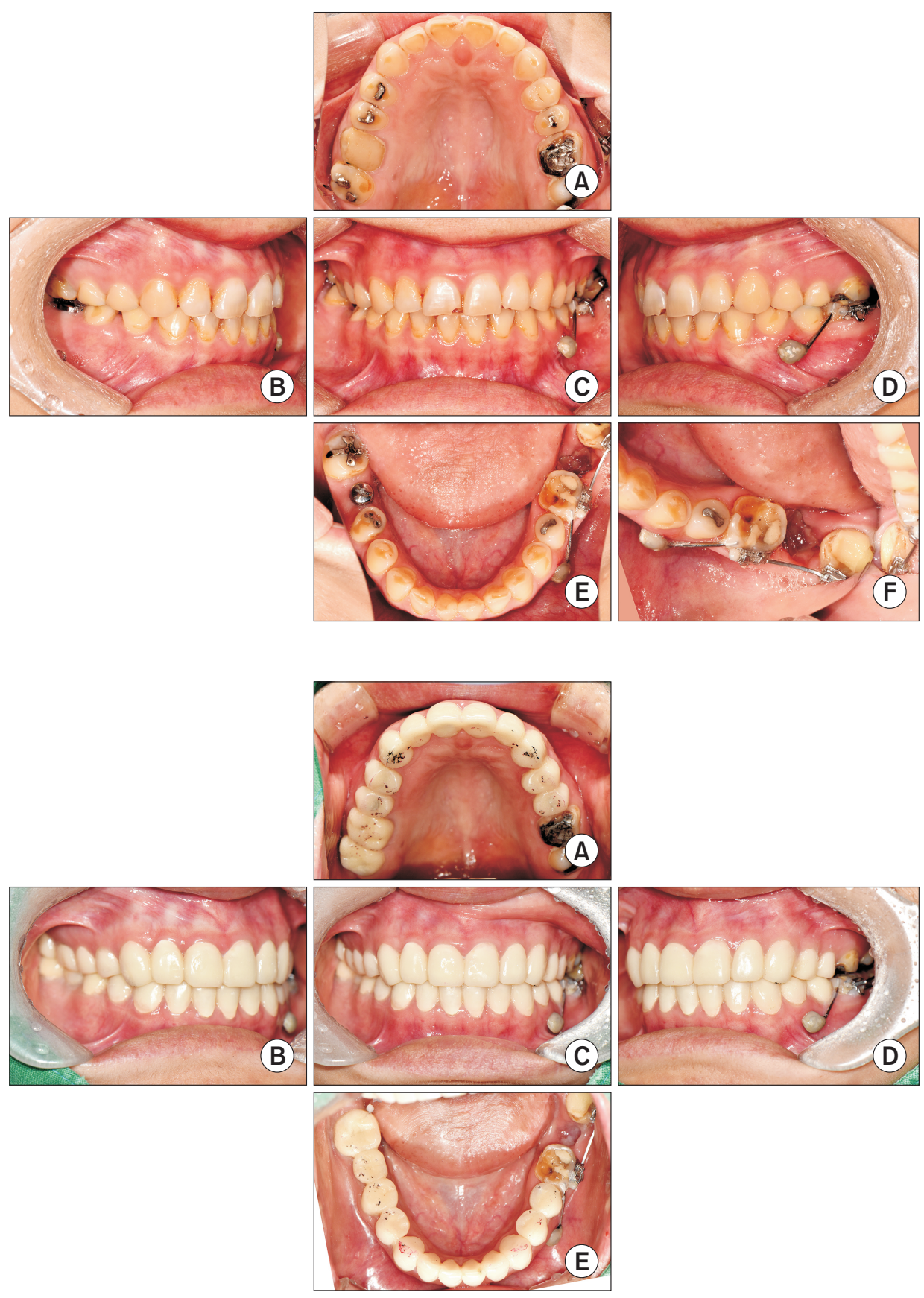

Fig. 7. Orthodontic treatment after \#37 extraction. (A) Maxillary occlusal view, (B) right lateral view, (C) frontal view, (D) left lateral view, (E) mandibular occlusal view, (F) occlusal view of \#38 traction

Fig. 8. Provisional restorations. (A) Maxillary occlusal view, (B) right lateral view, (C) frontal view, (D) left lateral view, (E) mandibular occlusal view.

튬 디실리케이트(IPS e.max Press; Ivoclar Vivadent, Schaan, Liechtenstein)로, 구치부는 보철물의 파절을 방지하고 심미성 을 위해 단일구조 지르코니아(Luxen Multi, DENTALMAX Co., Seoul, Korea)로 최종 수복 재료를 선택하고, computer-aided design/computer-aided manufacturing 이용하여 최종보철물 을 제작하였다(Fig. 11). 임플란트를 포함한 모든 고정성 보철물 은 단일 크라운으로 제작하였다. 최종보철물 시적하여 교합 조 정을 통하여 중심교합 위에서 모든 치아의 균등한 접촉과 하악
의 측방운동 시 견치유도 및 전방운동 시에는 상악 두 개의 중절 치에 의해 유도되는 것을 확인하였다. 교합조정 완료한 후 자연 치아의 고정성 보철물은 유지력 및 파절저항성이 우수한 이중 중합형 레진시멘트(Rely X Unicem; 3M ESPE, St. Paul, MN, USA)로, 임플란트 고정성 보철물은 조작이 쉽고 잉여시멘트 제 거가 용이한 레진강화형 글래스아이오노머 시멘트(FujiCEM 2, GC Co., Tokyo, Japan)을 이용하여 최종 합착하였다(Fig. 12). 그 대신 임플란트 고정성 보철물은 추후에 철거가 가능하도록 

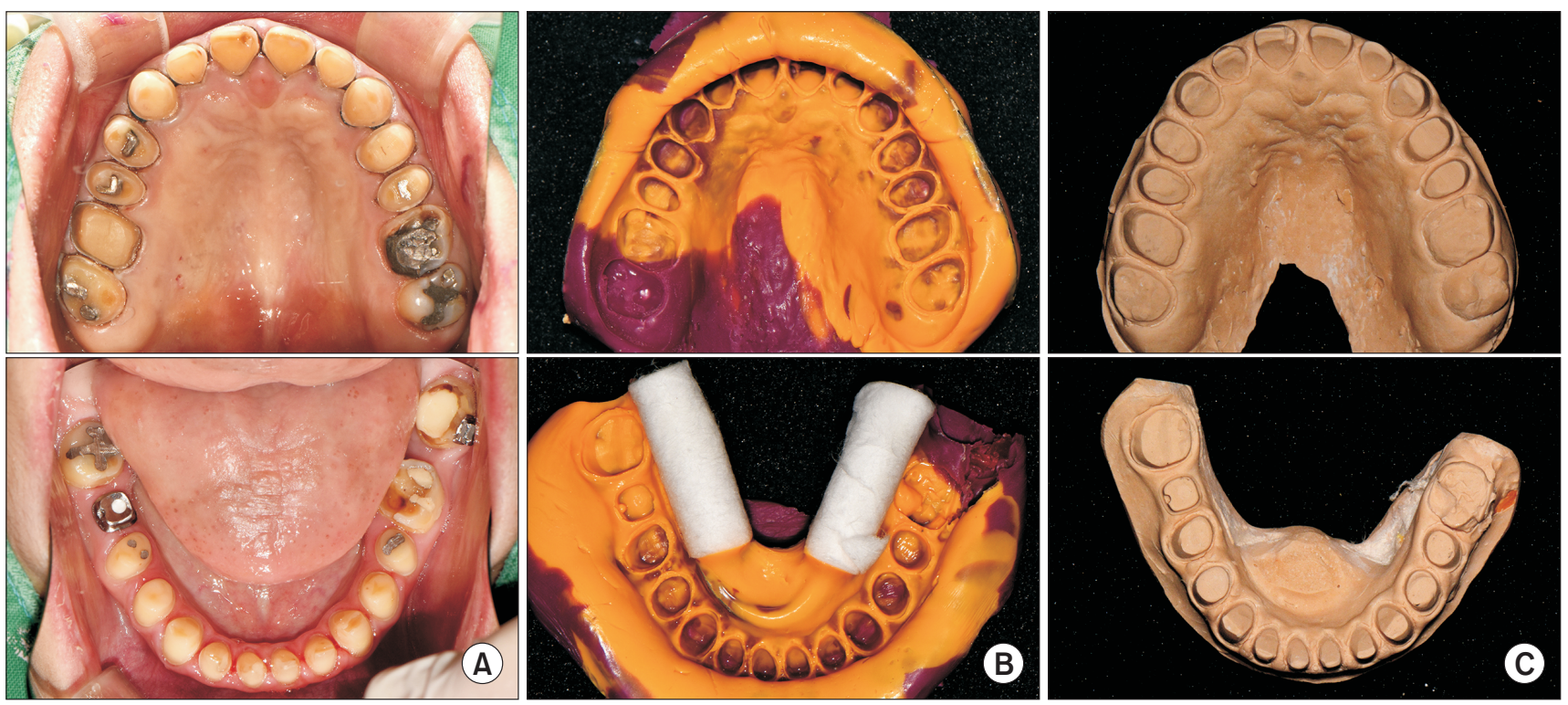

Fig. 9. Master cast fabrication. (A) Tooth final preparation, (B) final impression taking, (C) working model for fixed prosthesis.
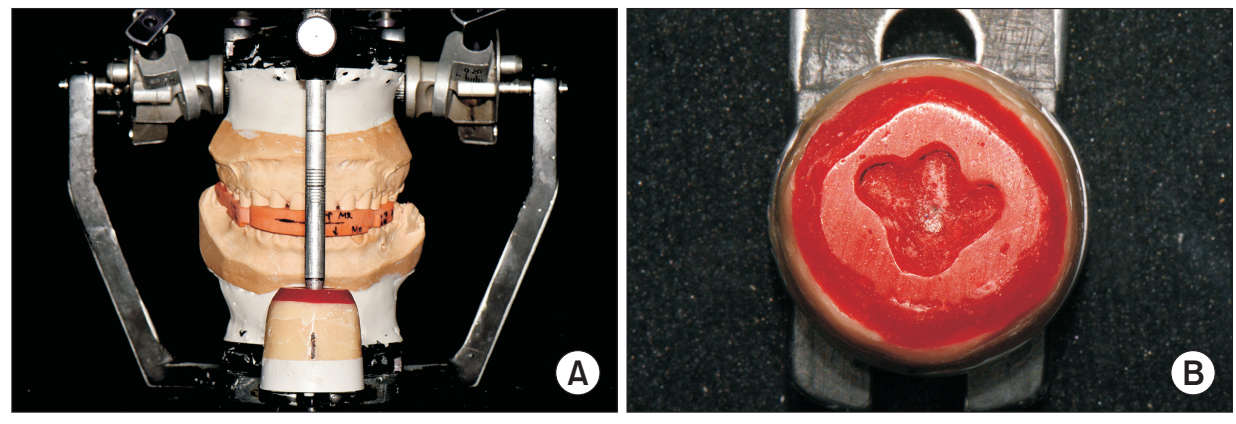

Fig. 10. The shape of anterior teeth and the occlusal relationship of provisional restorations are reflected in the definitive prosthesis. (A) Maxillary and mandibular models of provisional restoration mounted on articulator. (B) Customized anterior guide table.

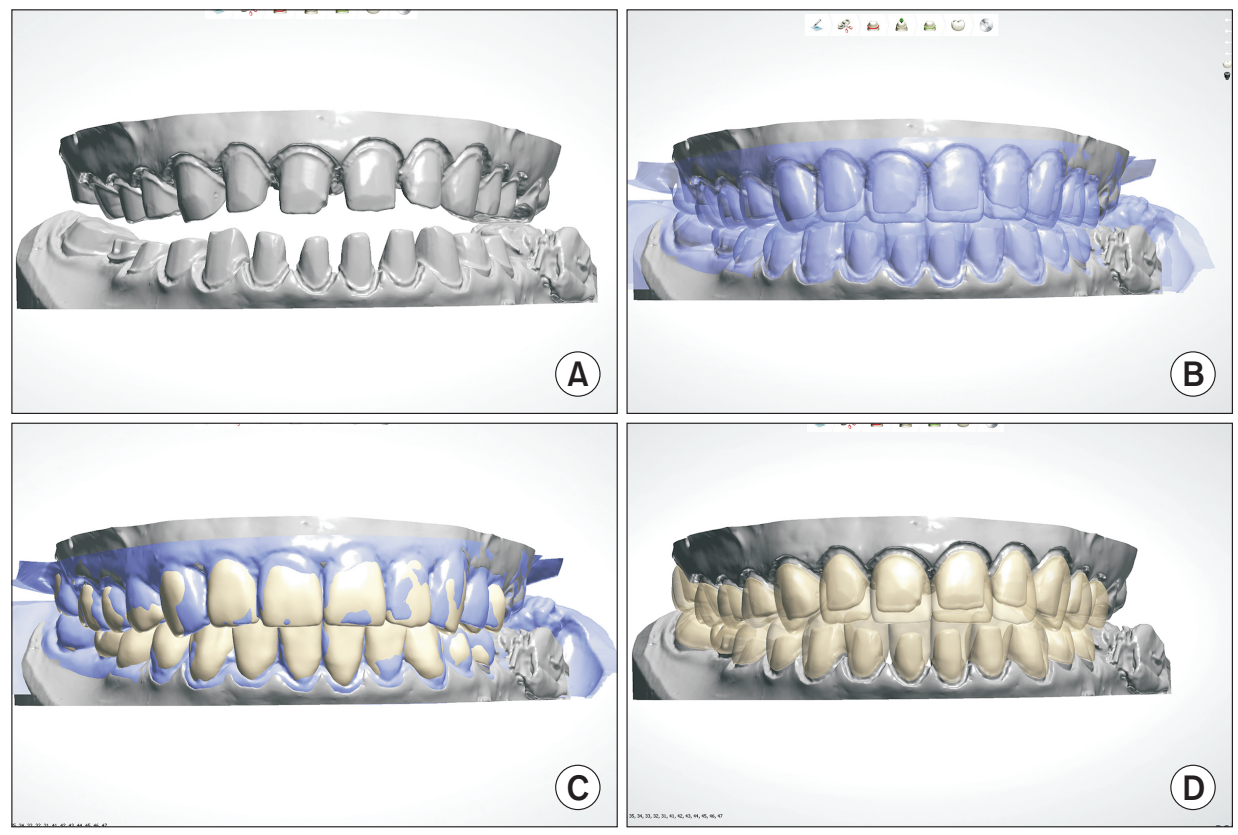

Fig. 11. Definitive prosthesis design procedure. (A) Virtual master cast. (B) Superimposition of provisional cast and master cast using double scanning. (C) Superimposition of provisional cast (blue) and final prostheses (white) (D) definitive prostheses. 


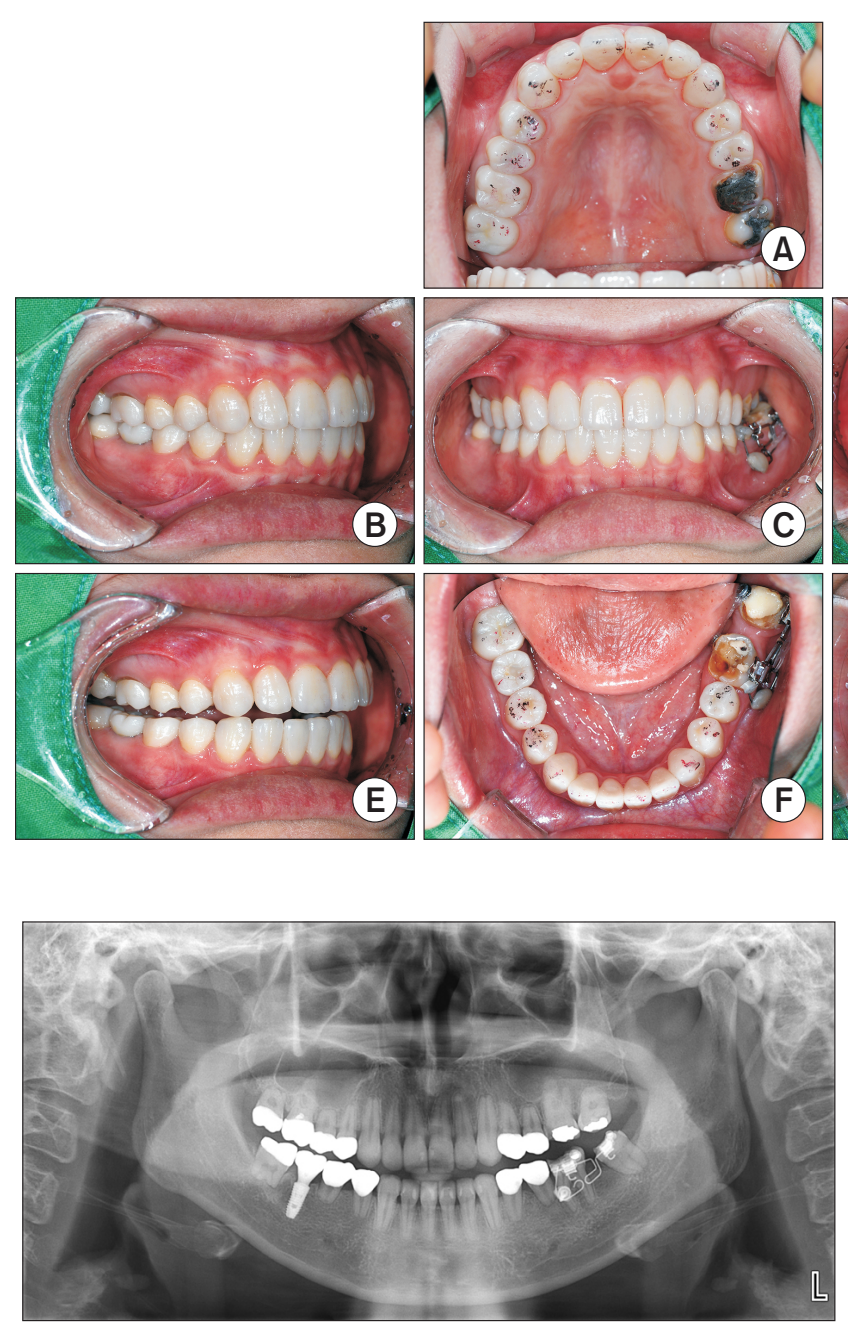

Fig. 13. Solving occlusal wear problems. Post-treatment panoramic radiograph.

나사-시멘트 유지형 보철물(screw-cement retained prosthe$\mathrm{Sis}$ 로 제작하였다. 도재의 파절을 막기 위해 상대적으로 제작이 간편한 연질의 교합안정장치를 취침 시에 사용하도록 하고 구 강 위생 교육을 실시하였다. 최종 수복물 장착 후, 정기적인 내 원을 통해 미세한 교합조정을 시행하였으며, 4 개월 간의 경과 관찰 기간 동안 특별한 합병증 없이 전 치열에 걸쳐 교합접촉이 안정적으로 유지되는 것을 확인하였다. 환자는 기능적으로 적 응하는 데에 문제점 없이 만족하였고, 심미적으로도 개선되어 만족하였다(Fig. 13).

\section{Discussion}

$\mathrm{SJS}$ 와 관련된 전신적인 합병증은 많은 보고가 있었지만 구강 악안면 관련 합병증으로는 치근의 불완전 발달에 관하여 드물

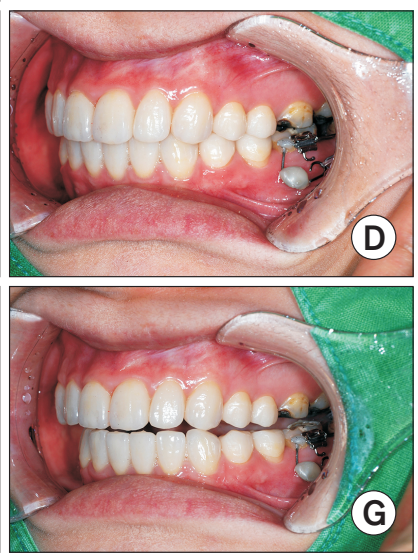

Fig. 12. Definitive prosthesis. (A) Maxillary occlusal view, (B) right lateral view, (C) frontal view, (D) left lateral view, (E) lateral movement-right side, (F) mandibular occlusal view, (G) lateral movement-left side.
게 보고가 되었다. 보고된 바에 따르면, SJS가 발병한 시기와 관 련하여 불완전하게 발달된 치근길이가 치아마다 다른 것이 특 징적이다. 즉, 치근이 발육되는 도중에 어떠한 기전에 의해 치근 발달이 정지된 것으로 추정할 수 있다. 그 외에 치관의 형태, 치 수강의 형태, 근관의 폭은 정상적인 범주를 보인다고 하였다. 또 한, 짧아져서 편평한 치근을 따라 존재하는 치주인대강도 정상 적이다[8]. SJS는 표피세포의 괴사로 인하여 나타나는 피부질환 이 주된 특징인데, 이러한 표피세포의 괴사가 치근을 발달시키 는 Hertwigs 상피치근집에 영향을 미쳐 치근의 발달이 정지된 것으로 추정할 수 있다[8,13]. 치아 발달 시기를 고려하였을 때, 환자의 상, 하악 4전치 및 제1대구치를 제외한 치아에서 치근발 달이 불완전한 상태인 것이 환자의 SJS 발현시기인 9세와 일치 하는 것은 이 가설을 강력하게 뒷받침한다. 이외에도 Ranalli 등 [14], Gaultier 등[15], Brook [16], Thornton과 Worley [17]의 보고에서도 이와 같은 SJS 발현시기와 치근 발육 중지 상태가 일 치한다고 하였다. 본 증례에서 다수의 치아에서 치근이 길이가 짧았으나, 증가된 동요도는 매우 작아서 일반적인 보철치료에 좋은 예후를 보일 것으로 생각되었다.

환자의 경우, 불완전한 치근발달 이외에도 전반적인 치아에 서 과도한 마모 및 방사선사진상 대체적으로 치아의 치수강이 매우 작은 소견을 보였다(Fig. 2). 특별하게 이상기능이나 식이 습관 혹은 역류성 위장관계 질환 등이 없음에도 불구하고 매우 젊은 여성에서 전반적인 치열의 심한 마모가 발생하였다는 점 에서 치아 이형성(dental dysplasia)과 같은 발달장애를 의심할 수 있지만 과도한 마모와 SJS와의 상관관계에 대한 연구결과는 
현재까지 보고된 바가 없다. 외배엽에서 유래한 내치아상피는 법랑질모세포로 분화하여 법랑질을 형성하며, 치관의 법랑질 형성이 완료되기까지는 약 5년 정도의 시간이 소요될 정도로 매 우 천천히 일어나는 과정인데, 이 기간 중 $2 / 3$ 는 성숙과정을 거 치게 된다. 법랑질 형성 성숙기의 마지막에 법랑질모세포는 치 아가 맹출할 때까지 새로 형성된 법랑질 표면을 보호하는 기능 을 한다. 이러한 법랑질모세포는 유전적 이형성(dysplasia) 이 외에도 열병, 테트라사이클린, 불소이온 등의 환경적 요인에도 민감하게 영향을 받는다[18]. 따라서 환자에게 나타나는 과도 한 마모는 SJS로 인한 고열 혹은 SJS에서 특징적으로 나타나는 표피세포 괴사가 법랑질모세포에 영향을 미쳐서 일어났을 가능 성이 있다. 치아가 맹출할 때까지 새로 형성된 법랑질을 보호하 는 법랑질모세포의 마지막 기능이 영향을 받아 법랑질 저형성 증(enamel hypoplasia)이 발생했을 수 있으며, 이로 인하여 환 자의 젊은 연령에 비해 과도한 마모가 나타났고, 이에 대한 방어 기전으로 치수강 폐쇄가 일어난 것으로 추정할 수 있다. 이러한 $\mathrm{SJS}$ 와 치아 이형성과의 관계는 더 추가적인 연구가 필요할 것으 로 사료된다.

모든 교합은 일생 동안 어느 정도 마모의 과정을 겪게 된다. 생리적 마모는 정상적인 현상으로 매우 느리게 진행되며 교두 의 풍융부 소실을 일으키고 구치 교두정을 편평하게 하며 전치 마멜론의 소실을 동반한다. 이러한 마모의 양은 길이나 깊이 면 에서 아주 소량으로 건전한 상태를 유지한다고 볼 수 있다[19]. 과도한 마모는 교합면에 치명적 손상을 야기하고 심미적인 면 이나 적절한 전방 유도를 위해 필요한 전치 구조를 파괴할 수 있 어 치열을 보호하기 위한 치료가 필요하다. 이러한 과도한 마모 로 인하여 수직 고경이 감소된 경우, 이를 회복시켜주는 것에 대 해서는 다양한 의견이 있어왔다. 수직고경의 변화는 구치부의 함입, 또는 전치부의 정출과 같은 부작용을 일으킨다는 주장이 있으나[19,20], 전 치열이 정확한 중심 위에서 적절히 교합되면 교합 관계를 개선하기 위해 수직 고경을 변화시키는 것이 가능 하다고 하였다[19]. 본 증례의 환자는 기능적으로 상악 전치 설 면의 과도한 마모로 전방유도가 상실되었으며, 구치부 교합면 의 심한 마모 및 부분파절로 저작효율이 감소하였다. 전반적으 로 치아가 닪은 양상을 보일 뿐만 아니라 상, 하악 전치부의 치 관길이 감소로 인하여 심미성 또한 감소되었다. 심한 마모 환자 의 치료 목표 중 하나는 중심위로부터 시작하는 편심위 하악운 동 시, 전방 치아에 의하여 구치부가 즉시 이개되는 것이며, 이 를 달성할 수 있는지 진단납형상에서 분석하는 것은 매우 필수 적이다. 또한 20대의 젊은 여성환자임을 고려하여 달라진 전방 교합관계로 절단연의 위치, 미소선 및 기능과 심미가 조화를 이 루도록 전치의 형태를 결정해야 한다. 중심위로 위치된 진단모 형에서 악간 공극, 발음, 안모 계측 및 심미성을 고려하여 상, 하
악 중절치 기준으로 $2 \mathrm{~mm}$ 를 거상하였고, 이를 통해 최소한의 치질 삭제로 보철물을 위한 수직적 공간을 확보할 수 있었고, 전 방유도기능도 손쉽게 부여할 수 있었다. 진단납형을 스캔하여 제작한 임시보철물을 장착하여 전 치열에 안정적이면서 저작효 율이 증가된 교합접촉을 형성해주었고, 하악 편심위 운동 시 견 치 및 전치 유도를 부여하였다. 임시수복 상태로 5 개월 간 경과 관찰하여 안정적인 교합상태 확인 후, 상, 하악 좌측 구치부를 제외하고 최종 수복물 제작하였으며, 최종 합착 후 4개월의 관 찰 기간 동안 합병증 없이 임상적으로 만족할 만한 결과를 보였 다. 비정상적인 치근발육을 보이는 SJS 환자의 치아가 심하게 마모되었다면, 병적인 동요가 없는 이상, 치관을 보철수복하는 것이 마모된 치아를 보호하고 추가적인 마모를 방지하며 상실 된 기능성과 심미성을 회복시킬 수 있다. 하악 좌측 제 2 대구치 (\#37) 상실부위에 대한 교정치료가 아직 진행 중이고, 교정치료 완료 후 상하악 좌측 구치부의 보철수복 치료는 여전히 남아있 는 상태이다. 교정치료가 진행되는 도중 및 완료된 이후에도 지 속적이고 정기적인 유지관리가 필요할 것으로 생각된다.

\section{Conflicts of Interest}

The authors declare that they have no competing interests.

\section{ORCID}

\author{
Yeon-Hee Park \\ http://orcid.org/0000-0002-9183-9244 \\ Ri Ryu \\ http://orcid.org/0000-0002-6356-9400 \\ Seung-Geun Ahn \\ http://orcid.org/0000-0002-9105-931X \\ Kyoung-A Kim \\ http://orcid.org/0000-0002-2923-5351 \\ Jae-Min Seo \\ http://orcid.org/0000-0001-5095-4046
}

\section{References}

1. Genetics Home Reference. Stevens-Johnson syndrome/ toxic epidermal necrolysis [Internet]. Bethesda: U.S. Department of Health \& Human Services [cited 2017 Apr 27]. Available from: https://ghr.nlm.nih.gov/condition/stevensjohnson-syndrome-toxic-epidermal-necrolysis.

2. von Hebra FR. On diseases of the skin. London: New Sydenham society; 1866. 
3. Stevens AM, Johnson FC. A new eruptive fever associated with stomatitis and ophthalmia. Am J Dis Child 1922;24:526533. doi: 10.1001/archpedi.1922.04120120077005.

4. Claxton RC. A review of 31 cases of Stevens-Johnson syndrome. Med J Aust 1963;50:963-967. doi: 10.5694/j.13265377.1963.tb18143.x.

5. Costello MJ. Erythema multiforme exudativum (erythema bullosum malignans; pluriorificial type); personal observations of cases in Willard Parker Hospital for contagious diseases (1932-1946). J Invest Dermatol 1947;8:127-144.

6. Bluefarb SM, Szanto P. Erythema multiforme associated with acute renal tubular necrosis. Arch Dermatol 1965;92:367372. doi: 10.1001/archderm.1965.01600160023005.

7. Wanscher B, Thormann J. Permanent anonychia after Stevens-Johnson syndrome. Arch Dermatol 1977;113:970. doi: 10.1001/archderm.1977.01640070104018.

8. De Man K. Abnormal root development, probably due to erythema multiforme (Stevens-Johnson syndrome). Int J Oral Surg 1979;8:381-385. doi: 10.1016/s03009785(79)80068-x.

9. Song JW, Leesungbok R, Park SJ, Chang SH, Ahn SJ, Lee $\mathrm{SW}$. Analysis of crown size and morphology, and gingival shape in the maxillary anterior dentition in Korean young adults. J Adv Prosthodont 2017;9:315-320. doi: 10.4047/ jap.2017.9.4.315.

10. Park JH, Jeong CM, Jeon YC, Lim JS. A study on the occlusal plane and the vertical dimension in Korean adults with natural dentition. J Korean Acad Prosthodont 2005;43:4151.

11. Willis FM. Features of the face involved in full denture prosthesis. Dent Cosm 1935;77:851-854.
12. Pleasure MA. Correct vertical dimension and freeway space. J Am Dent Assoc 1951;43:160-163. doi: 10.14219/ jada.archive.1951.0188.

13. Bajaj N, Madan N, Rathnam A. Cessation in root development: ramifications of 'Stevens-Johnson' syndrome. J Indian Soc Pedod Prev Dent 2012;30:267-270. doi: 10.4103/0970-4388.105023.

14. Ranalli DN, Elliott MA, Whaley TM, Campagna ED Jr. Stevens-Johnson syndrome: report of case with abnormal root development. ASDC J Dent Child 1984;51:298-301.

15. Gaultier F, Rochefort J, Landru MM, Allanore L, Naveau A, Roujeau JC, Gogly B. Severe and unrecognized dental abnormalities after drug-induced epidermal necrolysis. Arch Dermatol 2009;145:1332-1333. doi: 10.1001/archdermatol.2009.233.

16. Brook U. Stevens-Johnson syndrome and abnormal root development: a case report. Int J Paediatr Dent 1994;4: 101-103. doi: 10.1111/j.1365-263x.1994.tb00112.x.

17. Thornton JB, Worley SL. Short root anomaly in a patient with a history of Stevens-Johnson syndrome: report of case. ASDC J Dent Child 1991;58:256-259.

18. Nanci A. Enamel: composition, formation, and structure. In: Nanci A, editor. Ten Cate's oral histology: development, structure, and function. 7th ed. St. Louis: Mosby Elsevier; 2008. p. 141-190.

19. Dawson PE. Solving occlusal wear problems. In: Dawson PE, editor. Functional occlusion: from TMJ to smile design. St. Louis: Mosby Elsevier; 2007. p. 430-466.

20. Ramfjord SP, Blankenship JR. Increased occlusal vertical dimension in adult monkeys. J Prosthet Dent 1981;45:7483. doi: 10.1016/0022-3913(81)90015-9. 